\title{
Fabrication of Manila Hemp Fiber Reinforced Cross Ply Biodegradable Composites and Their Tensile Properties
}

\author{
Shinji Ochi \\ Department of Mechanical Engineering, National Institute of Technology, Niihama College, Ehime, Japan \\ Email: s_ochi@mec.niihama-nct.ac.jp
}

How to cite this paper: Ochi, S. (2018) Fabrication of Manila Hemp Fiber Reinforced Cross Ply Biodegradable Composites and Their Tensile Properties. Open Journal of Composite Materials, 8, 75-83. https://doi.org/10.4236/ojcm.2018.83007

Received: April 8, 2018

Accepted: June 30, 2018

Published: July 3, 2018

Copyright $\odot 2018$ by author and Scientific Research Publishing Inc. This work is licensed under the Creative Commons Attribution International License (CC BY 4.0).

http://creativecommons.org/licenses/by/4.0/

\section{(c) (i) Open Access}

\begin{abstract}
Natural plant fibers, including flax, kenaf, jute, bamboo, ramie and much more are renewable and sustainable resources and are considered good candidates for cost-effective alternatives to glass and carbon fibers. In this research, cross ply biodegradable composites were fabricated by press-forming method. The biodegradable composites consist of Manila hemp textile as a reinforcement and starch-based biodegradable plastics as a matrix was fabricated and investigated about mechanical properties. The tensile strength increased with the fiber content until fiber content of about $50 \%$ and leveled off thereafter. This dependence on the fiber content is due to the decrease in fiber strength of loading direction caused by fiber damages introduced during hot-pressing. In order to decrease the damage of fibers aligned in loading direction, Manila hemp textile was produced by using Manila hemp fibers for warp and biodegradable resin thread for weft. As a result, the tensile strength of cross ply composites increased from $153 \mathrm{MPa}$ to $202 \mathrm{MPa}$.
\end{abstract}

\section{Keywords}

Natural Fiber, Biodegradable Plastics, Manila Hemp, Biocomposites and Mechanical Properties

\section{Introduction}

These past few years have witnessed the speedy development of scientific techniques and an addition in the standard of living of human. However, these developments have their disadvantages. Fossil fuels were running out and there is insufficient space for our garbage. In order to reduce the environmental load generated from the disposal of used plastic products, significant attention has been placed on biodegradable resin. This resin can be completely resolved into water and carbon 
dioxide by the action of the microorganism, when it is disposed of in the soil. Moreover, there are no emissions of toxic gases during incineration. The application of biodegradable resin has been restricted due to their relatively lower strength compared to conventional plastics such as POM (polyacetal) and nylon. Resent years, because of their extensive use in many diverse fields, plastics, including FRP (fiber reinforced plastics) products have become indispensable to our life. However, the primary raw material used in plastic production is petroleum and there are strong social and economic pressures to conserve petroleum resources. Furthermore, because FRP wastes are non-flammable, they must be disposed of in landfills after use, and this contributes to high environmental loads. The use of natural plant fibers as a reinforcement in FRP to replace synthetic fibers such as glass and carbon fibers is presently receiving attention because of advantages such as renewable resources, low density and high specific strength. Furthermore, in recent years, development of biodegradable composites using natural plant fibers such as flax [1] [2], bamboo [3] [4], pineapple [5], silk [6], jute [7], kenaf [8] and ramie [9] [10] as a reinforcement and biodegradable resin as a matrix is conducted actively. And researches on molding condition, mechanical properties and interfacial bonding have been carried out.

In former paper [11], the research about development of high strength unidirectional Manila hemp fiber reinforced biodegradable composites was reported. The unidirectional biodegradable composites were made from Manila hemp fiber bundles and a starch-based emulsion-type biodegradable resin. The tensile and flexural strengths of the composites increased with increasing fiber content up to $70 \%$. The composites possessed extremely high tensile strengths of 365 $\mathrm{MPa}$. The aim of this study is to develop cross ply biodegradable composites to expand the range of applications of the biodegradable composites. Manila hemp textile was used as the reinforcement for cross ply biodegradable composites and investigated about their mechanical properties.

\section{Experimental Procedures}

\subsection{Materials}

As a matrix, emulsion-type biodegradable polymer (Miyoshi Oil \& Fat Co., LTD.,CP-300) was used. Plastic particles of approximately $5 \mu \mathrm{m}$ in diameter are suspended in water-based solution with a mass content of about $40 \%$. The properties of this biodegradable plastics are shown in Table 1. And biodegradable resin thread (Miyoshi Oil \& Fat Co., LTD., CPR-LF) as a weft for Manila hemp textile were used. This resin thread has same properties as matrix resin. Manila hemp fibers were provided by Fujiseishi Co., LTD in Japan. The dimensions of Manila hemp fibers are shown in Table 2. In this research, fiber bundles which have a diameter of about $200 \mu \mathrm{m}$ were used. In addition, the surface treatment of fibers was not carried out.

\subsection{Preliminary Molded Manila Hemp Textile}

Firstly, Manila hemp textiles of $100 \mathrm{~mm}$ square were produced using Manila 
hemp fibers with textile machine. Next, emulsion-type biodegradable polymer was put on the surface of Manila hemp fibers. The preliminary molded sheets were produced by drying at $105^{\circ} \mathrm{C}$ for $120 \mathrm{~min}$ in an oven. The photograph of Manila hemp textile produced is shown in Figure 1.

\subsection{Laminating Method}

As shown in Figure 2, cross ply composites were produced by laminating $0^{\circ}$ ply sheets and $90^{\circ}$ ply sheets alternately. $0^{\circ}$ ply laminates and $90^{\circ}$ ply laminates composites were also produced in the same manner.

\subsection{Molding Method}

Specimens were produced by the hot-pressing with a metallic mold and a press machine. Firstly, laminated preliminary molded sheets were put into the metallic mold, and then they were heated to $130^{\circ} \mathrm{C}$ with the flexible heater rolled around the metallic mold. Next it held at $130^{\circ} \mathrm{C}$ for $5 \mathrm{~min}$, and specimens were produced by pressing at $10 \mathrm{MPa}$ for $10 \mathrm{~min}$.

Table 1. Properties of biodegradable resin used as matrix.

\begin{tabular}{cc}
\hline Density $\left(\mathrm{g} / \mathrm{cm}^{3}\right)$ & 1.18 \\
\hline Melting point $\left({ }^{\circ} \mathrm{C}\right)$ & 58 \\
Water absorption $(\%)$ & 2 \\
Tensile strength $(\mathrm{MPa})$ & 11.7 \\
Young's modulus $(\mathrm{MPa})$ & 415 \\
\hline
\end{tabular}

Table 2. Dimensions of used manila hemp fibers.

\begin{tabular}{cccc}
\hline \multicolumn{2}{c}{ Fiber bundle } & \multicolumn{2}{c}{ Single fiber } \\
\hline Length $(\mathrm{m})$ & Diameter $(\mathrm{mm})$ & Length $(\mathrm{mm})$ & Diameter $(\mu \mathrm{m})$ \\
$2-3$ & $0.1-0.3$ & $2-12$ & $10-50$ \\
\hline
\end{tabular}

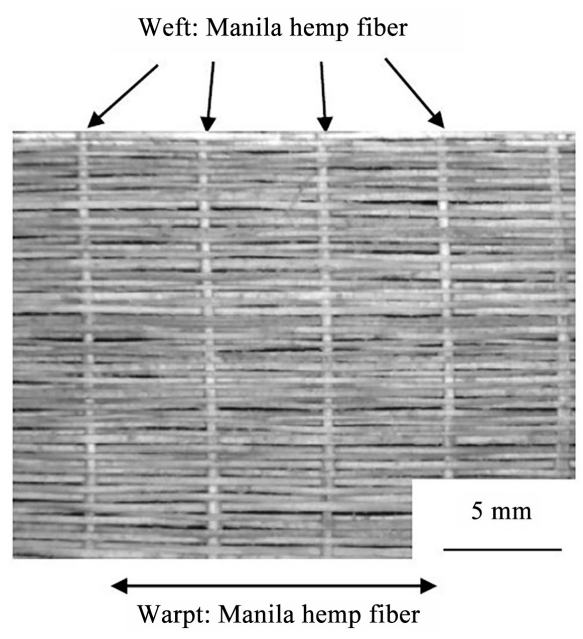

Figure 1. Aspect photograph of manila hemp textile. 


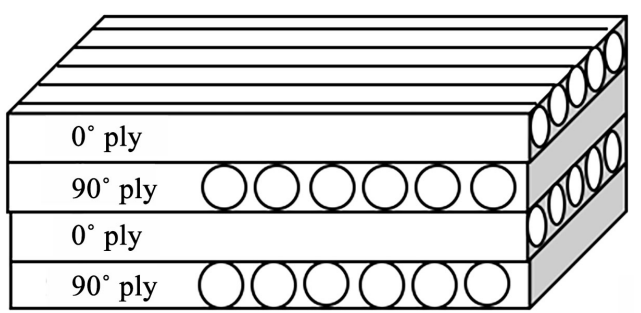

Figure 2. Schematic illustration of laminates.

\subsection{Mechanical Testing}

Tensile test was carried out by using 5567 type Instron testing machine. The width, thickness and length of the tensile specimen are $10 \mathrm{~mm}, 0.8-1.5 \mathrm{~mm}$ and $100 \mathrm{~mm}$, respectively. Tensile test was performed at a strain rate of 0.03 per min and the gauge length of $30 \mathrm{~mm}$. Figure 3 shows shape and dimensions of tensile specimen.

\section{Results and Discussions}

\subsection{Microstructure of Cross Ply Biodegradable Composites}

The top view and transverse section of fabricated cross ply biodegradable composites is shown in Figure 4 and Figure 5, respectively. From these figures, Manila hemp fibers distributed straight in bi-directions. From these figures, it can be observed that the distribution of fibers is parallel, and that there are no voids or fiber contacts that would cause a decrease in strength. To use an emulsion-type biodegradable resin, provides a suitable internal environment for achieving high fiber volume such as $60 \%$. And the density of the cross ply biodegradable composites indicates $1.09 \mathrm{~g} / \mathrm{cm}^{3}$.

\subsection{Tensile Properties of Cross Ply Biodegradable Composites}

Figure 6 shows the relationship between tensile strength of cross ply composites and fiber content. Figure 6 shows relationship between tensile strength and fiber content. Symbols of $\Delta, O, \nabla$ and $\square$ indicate tensile strength of $0^{\circ}$ ply laminates, cross ply laminates, $90^{\circ}$ ply laminates and biodegradable resin. From this figure, tensile strength reached $153 \mathrm{MPa}$ at $50 \%$ of fibers, but remain constant thereafter. The model of cross ply laminates is shown in Figure 7. The stress of parallel to loading direction and stress of parallel to vertical direction are expressed as op and $\sigma \mathrm{v}$, respectively. When applied stress is greater than $\sigma \mathrm{p}$, cross ply laminates will fracture. This fracture stress is given by Equation (1) [12]. Symbols of a and $\mathrm{b}$ indicate the thickness of $0^{\circ}$ ply and $90^{\circ}$ ply.

$$
\sigma=\sigma_{p} \cdot a /(a+b)
$$

Since the cross ply was laminated as $\mathrm{a}=\mathrm{b}$ in this research, fracture stress is given by Equation (2).

$$
\sigma=\left(\sigma_{p}+\sigma_{v}\right) / 2
$$




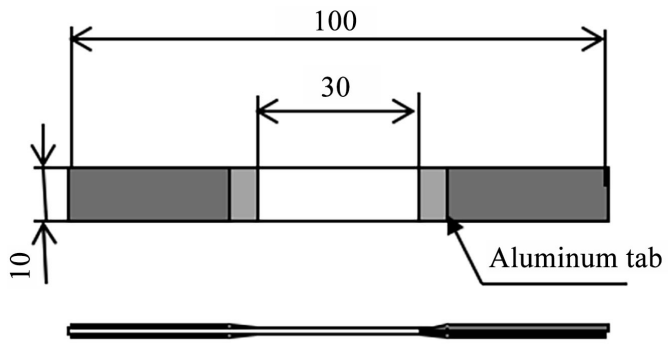

[Unit: $\mathrm{mm}$ ]

Figure 3. Shape and dimensions of tensile specimen.

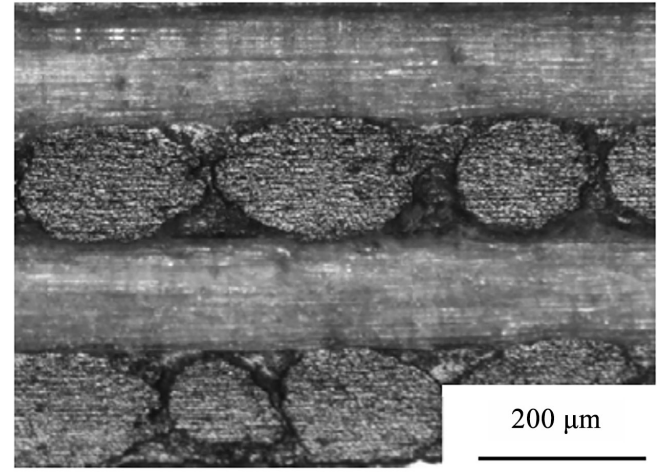

Figure 4. Top view of cross ply biodegradable composites.

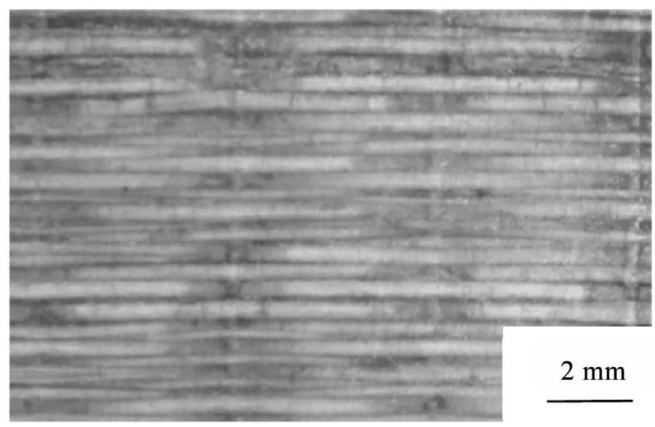

Figure 5. Optical micrograph of transverse section of cross ply biodegradable composites with $60 \%$ of fibers.

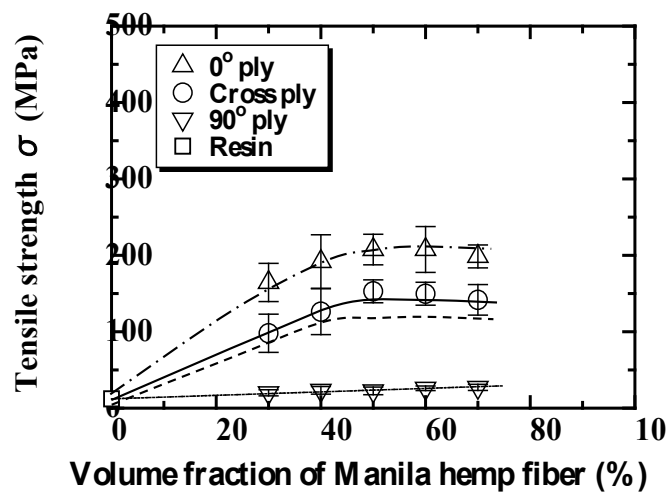

Figure 6. Relationship between tensile strength and volume fraction of Manila hemp fiber of biodegradable composites. 


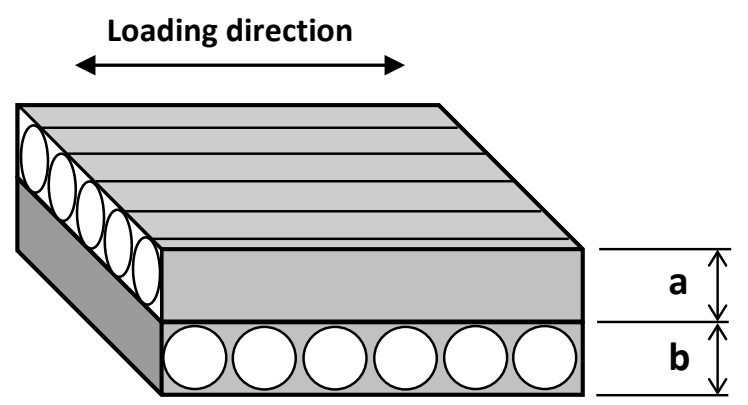

Figure 7. Schematic illustration of model for cross ply composites.

The dotted line in Figure 6 represents the theoretical strength value calculated from Equation (2). It can be seen that tensile strength properties of cross ply laminates significantly depend on the strength of $0^{\circ}$ ply laminates. As can be seen from fracture behavior of tensile specimen (Figure 8), the fibers parallel to loading direction were subject to getting damage by the fibers that intersected perpendicularly with the fibers parallel to loading direction. It was found that such fiber damage controls the fracture behavior of whole composites.

The experimental values of cross ply laminates are slightly higher than calculated values from Equation (2) in Figure 6, because of neglecting the strength of $90^{\circ}$ ply laminates. Taking into account the strength of $90^{\circ}$ ply laminates, the strength of cross ply laminates is given by Equation (3).

$$
\sigma=\left(\sigma_{p}+\sigma_{v}\right) / 2
$$

The solid line in Figure 6 is the theoretical strength calculated from Equation (3), and the strength obtained from Equation (3) shows a good agreement with experimental result.

\subsection{Development of High Strength Cross Ply Biodegradable Composites}

Figure 9 shows top view of Manila hemp textile made using Manila hemp fibers for warp and biodegradable resin thread for weft. And cross ply biodegradable composites were fabricated at same method as section 2.4. Top view of cross ply biodegradable composites was shown in Figure 10. From this figure, Manila hemp fibers were distributed parallel, furthermore biodegradable resin thread were mixed with biodegradable resin of matrix by heat during hot pressing.

Figure 11 shows relationship between tensile strength and fiber content. Symbols of $\triangle, O, \nabla$ and $\square$ indicate tensile strength of $0^{\circ}$ ply laminates, cross ply laminates, $90^{\circ}$ ply laminates and biodegradable resin. From this figure, both tensile strength of $0^{\circ} \mathrm{ply}$ laminates and cross ply laminates increase lineally with the fiber content until fiber content of $70 \%$. And at fiber content of $70 \%$, the cross-ply composites possessed extremely high tensile strength of $202 \mathrm{MPa}$, the tensile strength of cross ply composites using biodegradable resin thread for weft indicate high value than that of cross ply composites using Manila hemp fiber for weft. 
Figure 12 shows fracture behavior of cross ply composites after tensile test. In the case of specimen using Manila hemp fibers both warp and weft intersected perpendicularly with the fibers parallel to loading direction as shown Figure 7. However, in the case of specimen using biodegradable resin thread for weft cannot find influence of weft. Because the influence of the weft did not appear, tensile strength is guessed to be increase lineally with fiber content and indicate high strength than conventional composites.

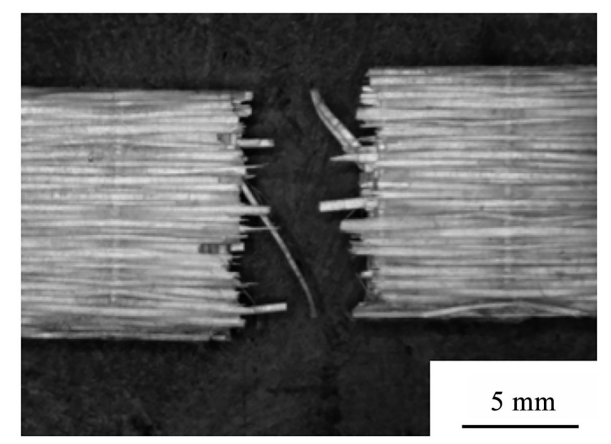

Figure 8. Fracture behavior of cross ply biodegradable composites reinforced by Manila hemp fibers.

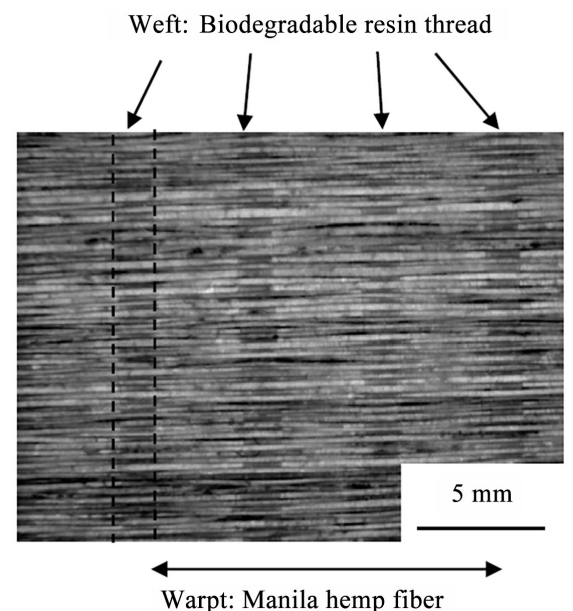

Figure 9. Aspect photograph of Manila hemp textile using biodegradable resin fiber for weft.

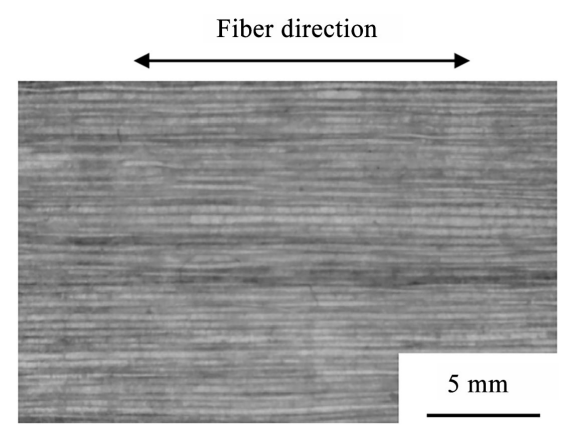

Figure 10. Top view of cross ply biodegradable composites using biodegradable resin thread for weft. 


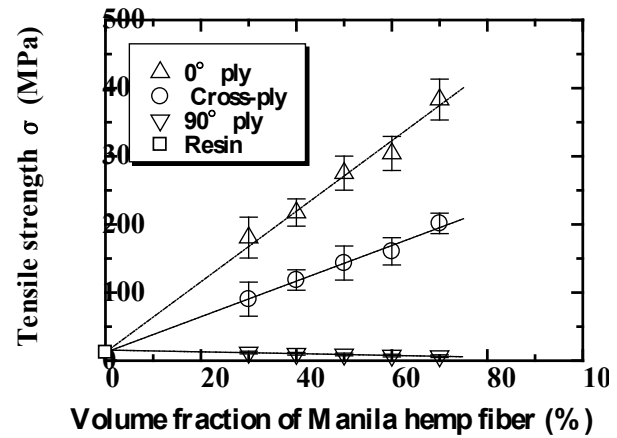

Figure 11. Relationship between tensile strength and volume fraction of Manila hemp fiber of biodegradable composites.

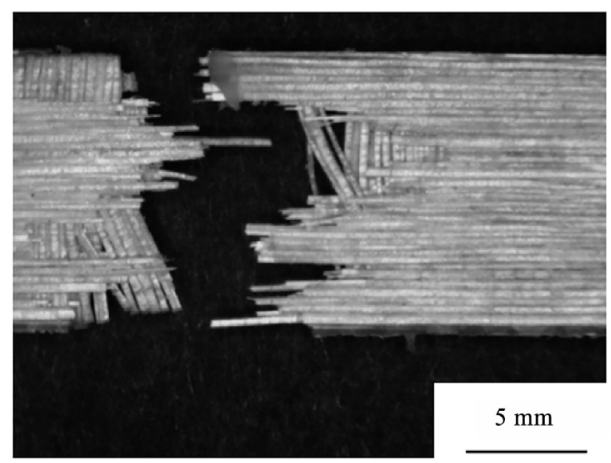

Figure 12. Fracture behavior of specimen after flexural test. Molding temperature of $160^{\circ} \mathrm{C}$. fiber content of $50 \%$.

\section{Conclusions}

This research was performed to examine the tensile properties of cross ply biodegradable composites that were made using an emulsion-type biodegradable resin as the matrix and Manila hemp textile as the reinforcement. The results obtained are as follows:

1) Using an emulation type biodegradable polymer and Manila hemp textile, cross ply biodegradable composites that their fibers are arranged straightly and fiber content is high were fabricated.

2) Tensile strength increased with the fiber content until $50 \%$ and remained constant thereafter. This fiber content dependence is due to the decrease in fiber strength caused by fiber damage introduced during hot-pressing.

3) Tensile strength of cross ply composites using biodegradable resin thread for weft increased lineally with the fiber content until fiber content of $70 \%$. And at fiber content of $70 \%$, the composites possessed extremely high tensile strength of $202 \mathrm{MPa}$.

\section{References}

[1] Perremans, D., Verpoest, I., Dupont-Gillain, C. and Van Vuure, A.W. (2018) Investigation of the Tensile Behavior of Treated Flax Fibre Bio-Composites at Ambient humidity. Composites Science and Technology, 159, 119-126.

https://doi.org/10.1016/j.compscitech.2018.02.038 
[2] Bulota, M. and Budtova, T. (2015) Highly Porous and Light-Weight Flax/PLA Composites. Industrial Crops and Products, 74, 132-138. https://doi.org/10.1016/j.indcrop.2015.04.045

[3] Huang, X.S. and Netravali, A. (2009) Biodegradable Green Composites Made Using Bamboo Micro/Nano-Fibrils and Chemically Modified Soy Protein Resin. Composites Science and Technology, 69, 1009-1015. https://doi.org/10.1016/j.compscitech.2009.01.014

[4] Liu, W., Misra, M., Askeland, P., Drzal, L. and Mohanty, A.K. (2005) “Green” Composites from Soy Based Plastic and Pineapple Leaf Fiber: Fabrication and Properties Evaluation. Polymer, 46, 2710-2721. https://doi.org/10.1016/j.polymer.2005.01.027

[5] Luo, S. and Netravali, A.N. (1999) Interfacial and Mechanical Properties of Environment-Friendly "Green" Composites Made From Pineapple Fibers and Poly(hydroxybutyrate-co-valerate)Resin. Journal of Materials Science, 34, 3709-3719. https://doi.org/10.1023/A:1004659507231

[6] Gao, A.L., Yang, Q. and Xue, L.X. (2016) Poly (L-Lactic acid)/Silk Fibroin Composite Membranes with Improved Crystallinity and Thermal Stability from Non-Solvent Induced Phase Separation Processes Involving Hexafluoroisopropanol. Composites Science and Technology, 132, 38-46. https://doi.org/10.1016/j.compscitech.2016.06.011

[7] Plackett, D., Andersen, T.L., Pedersen, W.B. and Nielsen, L. (2003) Biodegradable Composites Based on Polylactide and Jute Fibres. Composites Science and Technology, 63, 1287-1296. https://doi.org/10.1016/S0266-3538(03)00100-3

[8] Julkapli, N.M. and Akil, H.Md. (2008) Degradability of Kenaf Dust-Filled Chitosan Biocomposites. Materials Science and Engineering C, 28, 1100-1111. https://doi.org/10.1016/j.msec.2007.05.003

[9] Zhou, N.T., Yao, L., Liang, Y.Z., Yu, B., Yea, M.Q., Shanc, Z.D. and Qiu, Y.P. (2013) Improvement of Mechanical Properties of ramie/poly (lactic acid) (PLA) Laminated Composites Using a Cyclic Load Pre-Treatment Method. Industrial Crops and Products, 45, 94-99. https://doi.org/10.1016/j.indcrop.2012.12.014

[10] Lodha, P. and Netravali, A.N. (2005) Characterization of Stearic Acid Modified Soy Protein Isolate Resin and Ramie Fiber Reinforced "Green" Composites. Composites Science and Technology, 65, 1211-1225.

https://doi.org/10.1016/j.compscitech.2004.12.036

[11] Ochi, S. (2006) Development of High Strength Biodegradable Composites Using Manila Hemp Fiber and Starch Based Biodegradable Resin. Composites: Part A, 37, 1879-1883. https://doi.org/10.1016/j.compositesa.2005.12.019

[12] Hull and Clyne (1996) An Introduction to Composite Materials. 2nd Edition, Cambridge University Press, Cambridge. 